\title{
Anti-Tobacco Advertisement
}

National Cancer Institute

\section{Source}

National Cancer Institute. Anti-Tobacco Advertisement. NCI Thesaurus. Code C122676.

Advertisement designed to persuade individuals to cease, or not start, the use of tobacco. 